\title{
Kontribusi Bermain Peran untuk Mengembangkan Sosial-Emosional Anak Usia Dini
}

\author{
1MUHAMMAD AKIL MUSI, ${ }^{2}$ SADARUDDIN \\ ${ }^{3} \mathrm{MULYADI}$ \\ 1,2,3Universitas Negeri Makassar, Jl. Perintis Kemerdekaan KM.9 No.29, Tamalanrea Indah, Tamalanrea, Kota \\ Makassar, Sulawesi Selatan 90245 \\ Email: 1akrimna@yahoo.co.id, 2sadaruddinhm@yahoo.co.id \\ 3drmulyadi73@gmail.com
}

Article Received: 20-12-2017

Published Article: 03-04-2018

DOI: https://doi.org/10.29313/ga.v1i2.3315

\begin{abstract}
Social-emotional development is a very important stage in the lifespan of early childhood. The aimed of this research was to determine the effectiveness of the role play-based approach in developing early childhood social-emotional. The research method employed was descriptive qualitative research which analysis with interactive analysis model. The data collection technique is done through observation, interview, and documentation techniques. The results show that role-play approach are effectively develop early childhood socialemotional. Social-emotional learning activities using role play-based approach should be meet both motivation and interest of early childhood requirements.
\end{abstract}

Keywords: Role play, social-emotional development, and early childhood.

\begin{abstract}
Abstrak
Perkembangan sosial-emosional merupakan tahapan yang sangat penting dalam rentang kehidupan anak usia dini. Penelitian ini bertujuan untuk mengetahui makna bermain peran untuk mengembangkan kompetensi sosial-emosional anak usia dini. Metode penelitian yang digunakan adalah penelitian deskrptif kualitatif yang analisis dengan model analisis interaktif. Adapun teknik pengumpulan data dilakukan melalui pengamatan, wawancara dan teknik dokumentasi. Hasil penelitian menunjukkan bahwa bermain peran sangat efektif untuk mengembangkan kemampuan sosial-emosional anak usia dini. Dalam kegiatan pembelajaran sosial-emosional melalui bermain peran maka faktor yang harus diperhatikan adalah faktor motivasi dan minat anak.
\end{abstract}

Kata Kunci: Bermain peran, perkembangan sosial-emosional, dan anak usia dini.

\section{Pendahuluan}

Dalam perspektif pendidikan, anak adalah manusia yang berada dalam tahap krusial pertumbuhan dan perkembangan yang perlu mendapatkan perhatian yang optimal dan seimbang. Optimalisasi dan keseimbangan tersebut mengandung makna bahwa disamping sebagai seorang individu, anak adalah sosok sosial yang memutuhkan energi sosial untuk mematangkan perkembangan sosial emosionalnya. Oleh sebab itu maka secara simultan harus memperhatikan kedua hal tersebut yakni pola keberlangsungan kehidupan yang berdimensi sosial.

Kajian tentang prasekolah dikarakterisasi oleh para ilmuwan sebagai wahana bagi anak usia dini untuk memiliki yang sangat penting untuk mendorong interaksi anak-anak sebagai momentum yang terbaik dan kritis dalam rangka mengembangkan perkembangan anak usia dini (Yoshikawa et al., 2013). Untuk itu, perlu sekali memperhatikan kualitas interaksi sebab interaksi anak sangat dipengaruhi pendekatan seorang dalam berbagai karakteristik (Pianta et al., 2005). Terjadinya suatu interaksi yang tidak efektif dalam kegiatan pembelajaran anak di lembaga pendidikan (sekolah, taman kanak-kanak, dll), akan merugikan pola perkembangan sosial-emosional anak (McLean \& Connor, 2015). Beberapa penelitian menunjukkan bahwa kadang kala guru menjadi penyebab terjadinya distorsi sosial 
emosional anak karena guru kurang mampu mempersembahkan sebuah model pengajaran yang mampu memaksimalkan potensi sosial anak yang tentunya akan sangat berpengaruh dalam rentang kehidupan dan perkembangan anak (Curby, Brock \& Hamre, 2013).

Salah satu upaya yang dilakukan untuk mengembangkan kemampuan sosialemosional anak adalah model yang dikemukakan oleh Jennings \& Greenberg (2009) yang menawarkan suatu kerangka kerja yang disebut dengan pendidikan yang pro sosial. Konsepstualisasi pengajaran ini lebih menekankan pada hubungan antara guru dengan kualitas lingkungan yang sehat secara sosial dan mendukung perkembangan sosialemosional anak sehingga anak dapat berinteraksi secara positif dimana anak dapat menikmati suatu kehidupan yang harmonis dalam pola interaksi.

Salah satu hal yang penting diperhatikan dalam proses belajar mengajar anak adalah aspek perkembangan sosial. Hal ini disebabkan karena pembelajaran sosial- emosional melibatkan kesadaran diri anak, kesadaran sosial, keterampilan membuat keputusan, kemampuan untuk membangun hubungan dan kemampuan pengelolaan diri sendiri (Zins, Bloodworth, Weissberg dan Walberg, 2004). Pembelajaran yang pro sosial memiliki peran penting dalam kehidupan anak-anak. Masalah pembelajaran sosial-emosional seperti kekerasan, pelecehan anak, agresi, perilaku antisosial dan maladaptif nampaknya meningkat yang tentu mengkhawatirkan generasi terutama anak usia dini yang masih memiliki jalan panjang dalam petualangan kehidupan (Collie, et al., 2015) Selain itu, pembelajaran sosial-emosional juga berkontribusi pada kegiatan ekstrakurikuler anak-anak. Hal ini membuat pembelajaran sosial-emosional menjadi bagian penting dari pendidikan anak. Oleh karena itu, para guru memegang peran yang penting untuk membantu anak mengatasi masalah sosial-emosional mereka (Durlak et al., 2011).

Menurut Webster, Gaspar, \& Seabra (2012), pelaksanaan pembelajaran sosialemosional bertujuan untuk meningkatkan keterampilan pengelolaan kelas guru, mengembangkan hubungan guru-siswa dan membantu siswa memperoleh keterampilan sosial. Dalam hal ini, anak dapat mengatasi masalah serta memiliki keterampilan sosial yang memadai. Pengelolaan kelas yang menekankan aspek sosial dalam hal manajemen kelas maka akan mendorong terciptanya keterampilan dalam berkomunikasi serta pemerolehan sejumlah pengalaman yang berkesan dalam mengembangkan keterampilan sosialemosional (Karimzadeh et al, 2012).

Berdasarkan hal tersebut, guru harus membantu anak untuk memperoleh keterampilan akademis serta mengembangkan keterampilan sosial-emosional mereka. Guru yang memiliki kompetensi sosial dan emosional yang berkembang dengan baik akan mendorong anak dalam lingkungan pendidikan untuk ambil bagian dalam menyelesaikan konflik di antara mereka sendiri, membantu siswa berkolaborasi, dan membangun komunikasi positif di dalam dan di luar kelas (Greenberg \& Kusche, 2006).

Untuk mengembangkan kemampuan sosialemosional anak berbagai metode dapat dilakukan di lembaga pendidikan. Salah satu hal yang dapat dilakukan adalah bermain peran, baik dilakukan secara makro maupun secara mikro. Bermain peran adalah media yang tepat dalam mengajarkan anak karena dapat menawarkan suatu pembelajaran yang holistik bagi anak untuk memperoleh seperangkat pengalaman sosial (Rodgers \& Evans, 2008).

Berbagai penelitian pun telah membuktikan bahwa melalui bermain peran maka proses belajar mengajar dapat ditingkatkan di berbagai tingkat pendidikan dengan meningkatkan motivasi dan partisipasi aktif anak (Harris \& Daley, 2008). Manfaat bermain peran juga dikemukakan oleh Heyward (2010) yang menekankan bahwa bermain peran merupakan cara yang efektif untuk mengembangkan kemampuan sosial karena dapat melibatkan anak dalam dunia sosial yang memadai.

Selain itu, bermain peran juga dapat digunakan sebagai alternatif untuk mengembangkan kompetensi anak sehingga memungkinkan mereka dapat menjadi seorang yang memiliki kemampuan berinteraksi sosial yang berkualitas tinggi (Berry, Schmied, \& Schrock, 2008). Dalam permainan peran menurut Bolton and Heathcote (1999), anak akan dapat belajar dalam situasi sosial yang akan meningkatkan nilai dan kepercayaan, keterampilan berinteraksi sosial yang bermakna. Pemanfaatan kegiatan bermain peran (drama) akan dapat mengabadikan minat sosial anak termasuk dalam situasi pembelajaran (Van Ments, 1999). Demikian pula, dikemukakan bahwa partisipasi emosional dalam konteks bermain sosial (drama 
atau bermain peran) dapat menfasilitasi anak untuk memperoleh pemahaman yang lebih besar tentang motivasi, karakter dan kemauan untuk mengubah pendapat sebagai hasil keterlibatan ini (Walkinshaw, 2004). Berdasarkan hal tersebut maka mengingat pentingnya mengembangkan bahasa anak sebagai bagian yang tak terpisahkan dari kehidupan anak serta metode yang tepat dalam pengembangannya, maka perlu dilakukan kajian untuk mengetahui efektivitas penerapan bermain peran dalam upaya mengembangkan kemampuan sosialemosional anak agar dapat menjadi referensi dalam pengayaan perkembangan sosialemosional anak usia dini.

\section{Makna Bermain Peran}

Pengalaman yang menyenangkan sebagai suatu jalan dan jalur dalam bereksplorasi merupakan hakikat pembelajaran anak usia dini. Dalam kondisi demikian maka anak akan menemukan daya imajinasi dan fantasi yang kuat dan menyisakan kesan. Untuk itu, eksistensi bermain peran tidak hanya sebagai sebuah bentuk simulasi tanpa makna, melainkan mampu membawa anak pada cakrawala penjelajahan yang aktual dan faktual. Bermain peran sebagai refresentasi drama kehidupan anak tentunya dapat menjadi panggung yang efektif dalam mengoptimalisasi kemampuan anak terutama dalam dimensi kedirian atau pengembangan kesadaran diri.

Menurut Corey dan Corey (2006), suatu permodelan perilaku yang efektif adalah ketika seorang anak memiliki kesempatan untuk melakukan pengamatan dan replikasi. Dalam konteks bermain peran maka seorang anak akan mememerankan dalam atau purapura menjadi sesuatu sehingga akan menemukan di dalam sesuatu tersebut berbagai hal seperti pemahaman baru, pengalaman yang bermakna, imajinasi, daya hayal yang sesungguhnya merupakan dunia yang dicintai oleh seorang anak. Dalam hal ini, bermain peran dapat menjadi refresentasi kehidupan yang dijalani oleh pemeran yang memiliki hasrat untuk menemukan banyak hal mengenai diri dan kehidupannya.

Meski demikian, bukan kemampuan dalam bermain peran yang menjadi tujuan, melainkan efek yang dibawa dalam konteks metode ini seperti serapan informasi, personalisasi peran, persepsi, serta perilaku yang kesemuanya itu akan berkontribusi terhadap jiwa sosial emosional anak yang didalamnya terdapat "diri" dalam kesadarannya. Taylor et al. (2007) menyebutnya sebagai ruang eksplorasi dan wahana untuk berpartisipasi aktif yang nyaman dan aman dalam merumuskan dan mengungkapkan rasa yang ada. Sementara De Lange, Mitchell \& Bhana (2012), menginterpretasikan sebagai jalan untuk menemukan keyakinan diri karena dalam bermain peran, anak belajar tentang mengelola diri secara efektif untuk mengantar anak menemukan kecerdasan dirinya secara personal bahkan interpersonal sebagai bagian yang penting dalam kehidupan sosialnya.

\section{Lingkup Pembelajaran Sosial-emo- sional}

Pembelajaran sosial-emosional adalah suatu perspektif yang melibatkan kesadaran diri anak, kesadaran sosial, keterampilan membuat keputusan, kemampuan untuk membangun hubungan dan kemampuan pengelolaan konsep tentang diri anak. Menurut Ransford, Greenberg, \& Domitrovich (2009), pembelajaran sosial- emosional memiliki peran penting dalam kehidupan anak-anak karena anak akan memperoleh pengalaman yang dapat menjaga kehidupan sosial anak terutama ketika berada di luar lingkungan anak-anak sekolah untuk menerapkan beberapa aspek seperti pengakuan diri, penerimaan dan adaptasi, keterampilan berkomunikasi, empati, yang kesemuanya ini akan memberikan efek dan kesan pembelajaran yang akan berlangsung sepanjang hidup anak (Payton et. al., 2008).

Program pembelajaran sosial-emosional pada dasarnya bertujuan untuk meningkatkan keterampilan mengelola kelas yang memiliki peluang untuk mengembangkan hubungan dan keterampilan sosial yang handal. Webster \& Reid (2010) berpandangan bahwa untuk meningkatkan keterampilan sosial dalam kegiatan pembelajaran, dipandang perlu mengelola suatu paradigma pengalaman sosial yang tinggi. Untuk itu perlu menggunakan pendekatan yang dapat membangun interaksi sosial, teknik berkolaborasi, dan mengembangkan komunikasi positif.

Dalam konteks pembelajaran, maka salah satu landasan teori yang mendasari pembelajaran sosial-emosional anak adalah perlunya mengkaji berbagai pendekatan yang salah satunya adalah pendekatan mediasi. Mediasi sebagai instrumen pembelajaran 
merupakan konsep penting yang harus dibahas sebab terkait proses perkembangan mental anak. Berdasarkan konsep ini menurut Wertsch, Cole, \& Wertsch (2007), mediasi merupakan suatu konsep yang mendayagunakan alat sosial misalnya nilai dan sosial budaya dalam konteks pembelajaran. Pemanfaatan media sosial penting sekali sebab hal ini yang melingkari pola kehidupan anak sehari-hari yang dapat diterapkan dalam kegiatan belajar. Sehingga anak merasa terbawa dalam suatu kehidupan sosial yang nyata dan kontekstual sebab merasa familiar dengan aktivitas pembelajaran (Hollingsworth \& Winter, 2013).

\section{Instrumen Perkembangan Sosial- emotional Anak Usia Dini}

Kompetensi sosial dan emosional pada hakikatnya adalah kemampuan anak untuk mengelola diri dan hubungannya dengan orang lain. Instrumen kompetensi sosial menurut Greenberg et al., (2003) mencakup kemampuan untuk mengenali dan mengelola emosi, berempati dengan orang lain, membangun dan memelihara hubungan yang sehat, mengendalikan situasi sosial, membuat keputusan serta memiliki sikap yang bertanggung jawab. Kemampuan ini penting sejak awal kehidupan dan sangat relevan terutama ketika anak-anak berada dalam lingkungan sosial yang memungkinkan mereka melakukan berbagai interaksi dan sosialisai baik dengan teman sebaya dan orang dewasa sehingga tidak merasa asing dengan situasi sosial yang mengitarinya (Denham \& Brown, 2010).

Penelitian ini merujuk pada tahapan perkembangan bahasa sebagaimana diatur dalam Peraturan Menteri Pendidikan dan Kebudayaan (Permendikbud) Nomor 137 Tahun 2014 Tentang Standar Pendidikan Anak Usia Dini, disebutkan beberapa standar tingkat pencapaian perkembangan anak (STPPA) khususnya dalam hal perkembangan sosial-emosional yang meliputi kesadaran diri, tanggung jawab dan perilaku yang prososial, dapat dilihat pada Tabel 1. di bawah ini:

Tabel. 1. Lingkup Perkembangan Sosial-emosional Anak Usia 4-6 Tahun

\begin{tabular}{|c|c|c|}
\hline \multirow{2}{*}{$\begin{array}{l}\text { Ruang Lingkup } \\
\text { Perkembangan } \\
\text { Bahasa Anak }\end{array}$} & \multicolumn{2}{|c|}{ Usia (tahun) } \\
\hline & $4-5$ & $5-6$ \\
\hline \multirow{4}{*}{$\begin{array}{l}\text { Kesadaran diri, } \\
\text { tanggung jawab dan } \\
\text { perilaku yang pro } \\
\text { sosial }\end{array}$} & $\begin{array}{l}\text { Menunjukkan sikap mandiri dalam } \\
\text { memilih kegiatan }\end{array}$ & $\begin{array}{l}\text { Memperlihatkan kemampuan diri } \\
\text { untuk menyesuaikan dengan situasi }\end{array}$ \\
\hline & Menunjukkan rasa percaya diri & $\begin{array}{l}\text { Mentaati aturan kelas (kegiatan, } \\
\text { aturan) }\end{array}$ \\
\hline & $\begin{array}{l}\text { Menunjukan antusiasme dalam } \\
\text { melakukan permainan kompetitif } \\
\text { secara positif }\end{array}$ & Bermain dengan teman sebaya \\
\hline & Menghargai keunggulan orang lain & Berbagi dengan orang lain \\
\hline
\end{tabular}

Sumber: Permendikbud RI No. 137 Tahun 2014 Tentang Standar PAUD.

\section{Metode Penelitian}

Metode dan pendekatan penelitian ini adalah deskriptif kualitatif. Penelitian ini mengkaji dan menggambarkan situasi sosial sebagaimana dikemukakan oleh Saldana (2011) bahwa penelitian kualitatif memiliki karakteristik yang dapat mengungkap sejumlah makna dalam konteks sosial. Penelitian dilaksanakan di TK Al Fahri Kota Makassar selama 1 (satu) semester pada Kelompok B (usia 5-6 tahun) yang berjumlah 15 orang anak dengan prosedur penelitian yang dilakukan dalam penelitian ini adalah merujuk kepada tahapan sebagaimana yang dikemukakan oleh Creswell (1994: 147) yang secara garis besar dibagi kedalam tiga bagian, yaitu; 1) Tahapan persiapan/pra-lapangan, 2) Tahapan pekerjaan lapangan, dan 3) Tahapan analisis data.

Adapun teknik pengumpulan data dilakukan dalam penelitian ini adalah teknik pengamatan dan wawancara yang selanjutnya dianalisis dengan menggunakan langkahlangkah seperti yang dikemukakan oleh Miles dan Huberman (1994) berupa analisis model interaktif yang terdiri atas pengumpulan data, pemilahan data, penyajian data serta verifikasi dan pengambilan kesimpulan. Secara ringkas gambaran mengenai langkah analisis data model interaktif dapat dilihat pada gambar berikut ini: 


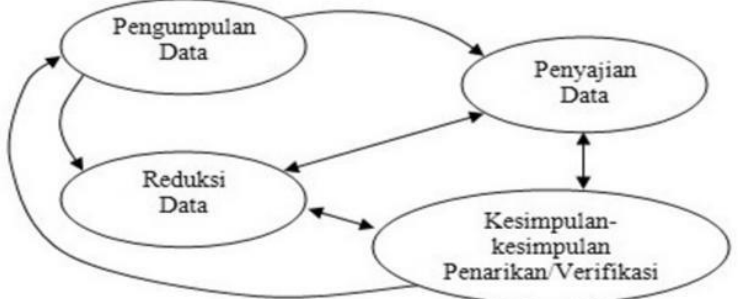

\section{Gambar: Analisis data model interaktif (Miles \& Huberman, 1994)}

Untuk memenuhi kriteria hasil yang handal, maka dilakukan uji keabsahan data penelitian ini dilakukan metode triangulasi dengan pendekatan metode dan sumber. Menurut Patton (1990: 169-186) triangulasi dengan sumber berarti membandingkan dan mengecek balik derajat kepercayaan suatu informasi yang diperoleh melalui waktu dan alat yang berbeda dalam penelitian kualitatif.

\section{Hasil dan Pembahasan}

Setelah dilakukan beberapa teknik pengumpulan data dan dianalisis baik secara kuantitatif (persentase) dan kualitatif (analisis hasil penilaian) terhadap indikator kemampuan sosial-emosional anak pada Triwulan I, maka diperoleh hasil penilaian yang disajikan pada tabel 2 . Di bawah ini:

\begin{tabular}{|c|c|c|c|c|}
\hline \multirow[t]{2}{*}{$\begin{array}{c}\text { Indikator Kemampuan } \\
\text { Sosial-emotional }\end{array}$} & \multicolumn{4}{|c|}{$\begin{array}{l}\text { Hasil Penilaian } \\
\text { Kompetensi } \\
\text { Sosial-emosional } \\
\text { Anak (frekuensi) }\end{array}$} \\
\hline & \multicolumn{4}{|c|}{ BB MB BSH BSB } \\
\hline $\begin{array}{l}\text { Kemampuan } \\
\text { menyesuaikan diri }\end{array}$ & 7 & 4 & 2 & 2 \\
\hline Mentaati peraturan kelas & 8 & 3 & 2 & 2 \\
\hline $\begin{array}{l}\text { Bermain dengan teman } \\
\text { sebaya }\end{array}$ & 9 & 2 & 1 & 3 \\
\hline $\begin{array}{l}\text { Menunjukkan sikap yang } \\
\text { mau berbagi dengan } \\
\text { teman (orang lain) }\end{array}$ & 7 & 4 & 1 & 3 \\
\hline
\end{tabular}

Tabel 2. Hasil Penilaian Kompetensi Sosial-emosional pada Triwulan ISumber: Hasil Penelitian, 2017.

Berdasarkan tabel 2. di atas, dapat dijelaskan bahwa hasil penilaian kemampuan sosial-emosional anak pada aspek kemampuan anak mengerti perintah secara bersamaan terdapat 7 anak $(46,67 \%)$ dalam kategori belum berkembang, $4(26,67 \%)$ anak berada pada kategori mulai berkembang, $2(13.33 \%)$ anak pada katagori berkembang sesuai harapan dan 2 (13.33\%) anak telah berada pada kategori berkembang sangat baik. Adapun rata-rata penilaian hasil belajar anak dapat dilihat pada tabel 3 di bawah ini:

Tabel 3. Rata-rata Penilaian Hasil belajar Anak Berdasarkan Kategori

\begin{tabular}{|c|c|c|c|c|}
\hline \multirow[t]{2}{*}{$\begin{array}{c}\text { Indikator } \\
\text { Kemampuan } \\
\text { Sosial-emotional }\end{array}$} & \multicolumn{4}{|c|}{$\begin{array}{c}\text { Hasil Penilaian } \\
\text { Kompetensi Sosial- } \\
\text { emosional Anak } \\
\text { (frekuensi) }\end{array}$} \\
\hline & BB & MB & $\mathrm{BSH}$ & BSB \\
\hline $\begin{array}{l}\text { Kemampuan } \\
\text { menyesuaikan diri }\end{array}$ & 7 & 4 & 2 & 2 \\
\hline $\begin{array}{l}\text { Mentaati } \\
\text { peraturan kelas }\end{array}$ & 8 & 3 & 2 & 2 \\
\hline $\begin{array}{l}\text { Bermain dengan } \\
\text { teman sebaya }\end{array}$ & 9 & 2 & 1 & 3 \\
\hline $\begin{array}{l}\text { Menunjukkan } \\
\text { sikap yang mau } \\
\text { berbagi dengan } \\
\text { teman (orang } \\
\text { lain) }\end{array}$ & 7 & 4 & 1 & 3 \\
\hline Jumlah & 31 & 13 & 4 & 10 \\
\hline Persentase (\%) & $56 . \underline{25}$ & 21.25 & 6.25 & 16.25 \\
\hline
\end{tabular}

Sumber: Hasil Penelitian, 2017.

Berdasarkan tabel 3 di atas, dapat dijelaskan bahwa rerata kemampuan anak pada kategori belum berkembang masih sangat tinggi yakni $56.25 \%$, kategori mulai berkembang ada $21,25 \%$, berkembang sesuai harapan terdapat 6,25 \% dan 16, 25 anak yang berkembang sangat baik. Hal ini jelas menunjukkan bahwa kompetensi yang diharapkan atau belum mencapai ketuntasan minimal sebagaimana digambarkan pada grafik rerata penilaian di bawah ini:

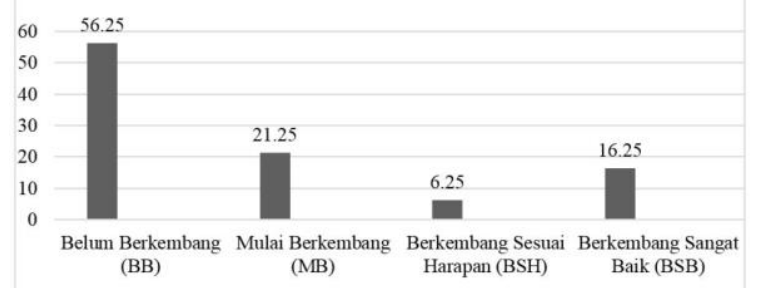

Gambar 1. Hasil Penilaian Triwulan I (Sumber: Hasil Penelitian, 2017)

Rendahnya rata-rata kemampuan sosial-emosional anak pada kategori berkembang sangat baik pada triwulan I setelah dilakukan refleksi diyakini disebabkan oleh faktor motivasi baik yang berasal dari diri anak (internal) maupun yang berasal dari luar anak (eksternal) yaitu faktor lingkungan yang belum dimodifikasi dengan baik. Adapun faktor motivasi dalam belajar menurut Steinhart \& Wyer (2009) menjelaskan bahwa untuk mencapai tujuan belajar yang 
optimal sangat ditentukan oleh motivasi anak terutama yang berhubungan dengan teknik guru dalam mengajarkan sesuatu obyek. Lee et. al. (2010) menegaskan bahwa untuk mancapai tujuan belajar yang diharapkan maka pembelajaran harus dibuat menarik agar dapat menarik minat anak dan memiliki motivasi yang tinggi dalam belajar.

Berdasarkan hasil yang ditunjukkan pada Triwulan I, maka pada Triwulan II dilakukan upaya sebagai jawaban atas refleksi pembelajaran yang telah dilakukan terutama dalam upaya mendorong minat anak serta melakukan perbaikan pada aspek lingkungan pembelajaran anak agar lebih menarik dan menyenangkan. Adapun hasil penilaian kemampuan anak pada siklus kedua dapat dilihat pada Tabel 4 di bawah ini:

\section{Tabel 4. Hasil Penilaian Kemampuan Anak pada Triwulan II}

\begin{tabular}{|c|c|c|c|c|}
\hline \multirow[t]{2}{*}{$\begin{array}{l}\text { Indikator Kemampuan } \\
\text { Sosial-emotional }\end{array}$} & \multicolumn{4}{|c|}{$\begin{array}{l}\text { Hasil Penilaian } \\
\quad \text { Kompetensi } \\
\text { Sosial-emosional } \\
\text { Anak (frekuensi) }\end{array}$} \\
\hline & & 3 & $\overline{\mathrm{BS}}$ & $\overline{\mathrm{BSB}}$ \\
\hline $\begin{array}{l}\text { Kemampuan } \\
\text { menyesuaikan diri }\end{array}$ & 2 & 1 & 1 & 11 \\
\hline Mentaati peraturan kelas & 1 & 1 & 1 & 12 \\
\hline $\begin{array}{l}\text { Bermain dengan teman } \\
\text { sebaya }\end{array}$ & 1 & 2 & 1 & 11 \\
\hline $\begin{array}{l}\text { Menunjukkan sikap yang } \\
\text { mau berbagi dengan } \\
\text { teman (orang lain) }\end{array}$ & 1 & 1 & 2 & 11 \\
\hline
\end{tabular}

Sumber: Hasil Penelitian, 2017.

Berdasarkan Tabel 4. Di atas dapat dijelaskan bahwa hasil penilaian kemampuan berbahasa anak pada aspek kemampuan anak mengerti perintah secara bersamaan hanya terdapat 2 anak (13.33 \%) dalam kategori belum berkembang, 1 (6.66 \%) anak berada pada kategori mulai berkembang, 1 (6.66 \%) anak pada katagori berkembang sesuai harapan dan 11 (73,33 \%) anak telah berada pada kategori berkembang sangat baik. Adapun rata-rata penilaian hasil belajar anak dapat dilihat pada tabel 5 di bawah ini:

\section{Tabel 5. Rata-rata Penilaian Hasil belajar Anak Berdasarkan Kategori}

\begin{tabular}{|c|c|c|c|c|}
\hline $\begin{array}{c}\text { Indikator } \\
\text { Kemampuan }\end{array}$ & \multicolumn{4}{|c|}{$\begin{array}{c}\text { Hasil Penilaian Kompetensi } \\
\text { Sosial-emosional Anak } \\
\text { (frekuensi) }\end{array}$} \\
\hline Sosial-emotional & $\mathrm{BB}$ & MB & $\mathrm{BSH}$ & BSB \\
\hline $\begin{array}{l}\text { Kemampuan } \\
\text { menyesuaikan } \\
\text { diri }\end{array}$ & 2 & 1 & 1 & 11 \\
\hline
\end{tabular}

\begin{tabular}{|c|c|c|c|}
\hline Mentaati & 1 & 1 & 12 \\
\hline $\begin{array}{l}\text { Bermain dengan } \\
\text { teman sebaya }\end{array}$ & 1 & 2 & 11 \\
\hline $\begin{array}{l}\text { Menunjukkan } \\
\text { sikap yang mau } \\
\text { berbagi dengan } \\
\text { teman (orang } \\
\text { lain) }\end{array}$ & 1 & 1 & 11 \\
\hline Jumlah & 5 & 5 & 45 \\
\hline Persentase (\%) & $\begin{array}{l}8.338 .33 \\
\%\end{array}$ & $3 \% 8.33 \%$ & $\% 75.00$ \\
\hline
\end{tabular}

Sumber: Hasil Penelitian, 2017.

Berdasarkan tabel 5. Di atas dapat dijelaskan bahwa rerata kemampuan anak pada kategori belum berkembang masih sangat tinggi yakni $75.00 \%$, sedangkan anak yang telah berkembang sangat baik hanya mencapai 8.33 \%. Pada kategori lainnya yakni mulai berkembang dan berkembang sesuai harapan masing-masing 8,33\%. Hal ini jelas menunjukkan bahwa kompetensi yang diharapkan telah mencapai ketuntasan minimal sebagai hasil yang harus dicapai oleh anak yakni $70 \%$ anak yang berkembang sangat baik maka pembelajaran dapat dikatakan telah memenuhi ketuntasan minimal secara klasikal, seperti digambarkan pada grafik penilaian di bawah ini

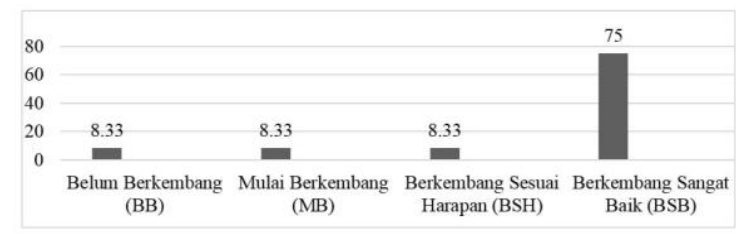

\section{Gambar 2. Hasil Penilaian pada Triwulan II (Sumber: Hasil Penilaian, 2017)}

M e n i n g k a t n y a has i l pe n i la i a $n$ kemampuan sosial -emosional sebagaimana telah dijelaskan di atas, karena guru telah berhasil melakukan perbaikan dalam proses pembelajaran. Salah satu hal yang dilakukan adalah membuat anak tertarik atau dapat menumbuhkan minat anak dalam belajar. Faktor minat memang sangat memperngaruhi anak dalam kegiatan belajar mengajar. Hal ini dibenarkan oleh Hofer (2010) yang menegaskan bahwa pengembangan minat sangat mempengaruhi tujuan pembelajaran. Sementara itu, Hoffmann (2002) mengamati bahwa, kehilangan minat terhadap masalah pembelajaran di sekolah terutama ketika anak berada dalam masa transisi. Minat dapat berkembang lebih baik jika individu terlibat dalam kegiatan pembelajaran yang 
Golden Age: Jurnal Pendidikan Anak Usia Dini, Volume 1 Nomor 2 (Desember 2017)

MUHAMMAD AKIL MUSI, SADARUDDIN, MULYADI / Kontribusi Bermain Peran untuk Mengembangkan Sosial-Emosional Anak Usia Dini

menyenangkan yang pada akhirnya akan mempengaruhi hasil belajar anak (Krapp, 2002).

\section{Kesimpulan}

Berdasarkan analisis data yang telah dilakukan baik dalam pendekatan kualitatif dan kuantitatif dimana rerata kemampuan anak pada kategori belum berkembang masih sangat tinggi yakni $75.00 \%$, sedangkan anak yang telah berkembang sangat baik hanya mencapai 8.33 \%. Pada kategori lainnya yakni mulai berkembang dan berkembang sesuai harapan masing-masing 8,33 \%. Hal ini jelas menunjukkan bahwa kompetensi yang diharapkan telah mencapai ketuntasan minimal sebagai hasil yang harus dicapai oleh anak yakni $70 \%$ anak yang berkembang sangat baik maka pembelajaran dapat dikatakan telah memenuhi ketuntasan minimal secara klasikal. Oleh karena itu dapat disimpulkan bahwa bermain peran sangat efektif dalam rangka mengembangkan kemampuan perkembangan sosial-emosional anak. Untuk mengembangkan kemampuan sosial-emosional dalam metode pembelajaran yang perlu mendapatkan perhatian dari guru adalah faktor motivasi dan minat, sebab kedua hal ini mempengaruhi hasil belajar dan kompetensi anak yang meliputi kesadaran diri, rasa tanggung jawab dan perilaku yang prososial.

Tindak lanjut dari kesimpulan, maka hal yang perlu direkomendasikan adalah bahwa kegiatan bermain peran baik makro ataupun mikro sangat efektif untuk meningkatkan kemampuan bahasa anak. Selanjutnya dalam pelaksanaan bermain peran, guru harus memperhatikan beberapa faktor-faktor yang mempengaruhi keberhasilan anak dalam kegiatan belajar mengajar yaitu faktor motivasi dan minat anak.

\section{Daftar Pustaka}

Berry, C., Schmied, L. A., \& Schrock, J. C. (2008). The Role of Emotion in Teaching and Learning History: A Scholarship of Teaching Exploration. The History Teacher, 41(4), 437-452.

Bolton, G., \& Heathcote, D. (1999). So You Want to Use Role Play? A New Approach in How to Plan. Stoke on Trent, UK: Trentham Books. Collie, R. J., Shapka, Jennifer D., Nancy P. E. \& Martin, A. J. (2015). Teachers' Beliefs About Social-emotional Learning: Identifying
Teacher Profiles and Their Relations with Job Stress and Satisfaction. Learning and Instruction 39, 148-157.

Corey MS \& Corey G 2006. Groups: Processes and Practice (7th ed). New York: Thompson Brooks/Cole.

Creswell, John W., (1994), Research Design ; Qualitative and Quantitative Approaches, California : SAGE Publications.

Curby, Brock \& Hamre, (2013). Teachers' Emotional Support Consistency Predicts Children's Achievement Gains and Social Skills. Early Education \& Development, 24(3), 292-309

De Lange N, Mitchell C \& Bhana D 2012. Voices of women teachers about gender inequalities and gender-based violence in rural South Africa. Gender and Education, 24:499-514.

Denham, Susanne A., \& Brown, Chavaughn. (2010). Plays Nice with Others: Social Emotional Learning and Academic Succes. Early Education and Development, 21, 652-680.

Durlak, J. A., Weissberg, R. P., Dymnicki, A. B., Taylor, R. D., \& Schellinger, K. B. (2011). The Impact of Enhancing Students' Social and Emotional Learning: A Meta-analysis of School-based Universal Interventions. Child development, 82(1), 405-432.

Greenberg et. al (2003). Enhancing Schoolbased Prevention and Youth Development Through Coordinated Social, Emotional, a $\mathrm{n}$ d A c a d e m i c L e a r n ing. $A m$ e $r$ i c a n Psychologist, 58(67),-466- 474.

Greenberg, M. T. ve Kusche, C. A. (2006). Building Social And Emotional Competence: The Paths Curriculum. In S. R. Jimerson \& M. J. Furlong (Eds.), Handbook Of School Violence And School Safety (pp. 395- 412). Mahwah, NJ: Lawrence Erlbaum.

Harris, P., \& Daley, J. (2008). Exploring The Contribution of Play To Social Capital In Institutional Adult Learning Settings. Australian Journal of Adult Learning, 48(1), 50-70.

Heyward, Paul. (2010). Emotional Engagement Through Drama: Strategies to Assist Learning through Role- Play. International Journal of Teaching and Learning in Higher Education 2010, Volume 22, Number 2, 197-203

Hofer, M. 2010, Adolescents' Development of Individual Interests: A Product of Multiple GoalRegulation?. Educational Psychologist, 45(3), 149-166, 2010

Hoffmann, L. 2002. Promoting Girls' Interest and Achievement in Physics Classes for Beginners. Learning and Institution, Volume 12 (4), 447-465.

Hollingsworth, H. L. \& Winter, M. K. (2013). 
Teacher Beliefs And Practices Relating To Development In Preschool: Importance Placed On Social-Emotional Behaviours And Skills. Early Child Development and Care, 183(12), 1758-1781.

Jennings, P. A., \& Greenberg, M. T. (2009). The Prosocial Classroom: Teacher Social And Emotional Competence In Relation To Student And Classroom Outcomes. Review of Educational Research, 79, 491-525.

Karimzadeh, M., Goodarzi, A. and Rezaei, S. (2012). The Effect Of Social-Emotional Skills Training To Enhance General Health\& Emotional Intelligence In The Primary Teachers. Social and Behavioral Sciences. 46, $57-64$.

Krapp, A. (2002). An Educational-psychological Theory of Interest and its Relation to SelfDetermination Theory. In: E. Deci

\& R. Ryan (Eds), The Handbook of SelfDetermination Research (pp. 405-427). Rochester: University of Rochester Press.

Lee, E., Mc. Inerney, D. M., Liem, G. A. D., \& Ortiga, Y. P. (2010). The Relationship Between Future Goals and Achievement Goal Orientations: An Intrinsic-extrinsic Motivation Perspective. Contemporary Educational Psychology, 10, 1-16.

McLean, L., \& Connor, C. M. (2015). Depressive Symptoms In Third -Grade Teachers: Relations To Classroom Quality And Student Achievement. Child Development, 86 (3), 945-954.

Miles, Matthew B. \& Huberman, A. Michael. (1994). Qualitative Data Analysis: An Expanded Sourcebook. New York: Sage Publications

Patton, Michael Quinn. (1990). Qualitative Evaluation and Research Methods. Beverly Hills, CA: Sage.

Payton, J., Weissberg, R. P., Durlak, J. A., Dymnicki, A. B., Taylor, R. D., Schellinger, K. B., \& Pachan, M. (2008). The Positive Impact of Social and Emotional Learning for Kindergarten to Eighth-Grade Students: Findings from Three Scientific Reviews. Technical Report. Collaborative for Academic, Social, and Emotional Learning (NJ).

Pianta, R. C., Howes, C., Burchinal, M., Bryant, D., Clifford, R., Early, C., \& Barbarin, O. (2005). Features Of Prekindergarten Programs, Classrooms, And Teachers: Do They Predict Observed Classroom Quality And Child-Teacher Interactions? Applied Developmental Science, 9, 144-159.

Ransford, C. R., Greenberg, M. T. \& Domitrovich, C. E. (2009). The Role of Teachers' Psychological Experiences And Perceptions Of Curriculum Supports On The Implementation Of A Social
And Emotional Learning Curriculum. School Psychology Review, 38(4), 510 -532.

Rodgers, S. and Evans, J. (2008). Inside Role-Play in Early Childhood Education: Researching Young Children's Perspective. Routledge: U.S.A. Santrock

Saldana, Johnny. (2011). Fundamentals of Qualitative Research. New York: Oxford University Press, Inc.

Steinhart, Y., \& Wyer, R. S. (2009). Motivational Correlates of Need for Cognition, European Journal of Social Psychology, 39, 608-621.

Taylor, Myra et al. (2012). Exploring The Use Of Role Play In A School-Based Programme To Reduce Teenage Pregnancy. South African Journal of Education, Volume 32(4), 441-448.

Van Ments, M. (1999). The Effective Use Of RolePlay: Practical Techniques for Improving Learning. London, UK: Kogan Page.

Walkinshaw, A. D. (2004). Integrating Drama With Primary And Junior Education: The Ongoing Debate. Lewiston, NY: Edwin Mellen Press.

Webster-Stratton, C. \& Reid, M. J. (2010). The Incredible Years Parents, Teachers, And Children Training Series: A Multifaceted Treatment Approach For Young Children With Conduct Disorders. In J. R. Weisz

\& A. E. Kazdin (Eds.) Evidence-Based Psychotherapies for Children and Adolescents (pp. 194-210). New York and London: The Guilford Press.

Webster, Stratton, C., Gaspar, M. F. and Seabra, Santos, M. J. (2012). Incredible Years Parent, Teachers And Children's Series: Transportability To Portugal Of Early Intervention Programs For Preventing Conduct Problems And Promoting Social And Emotional Competence. Psychosocial Intervention, 21(2), 157-169.

Wertsch, J. V.; H. D., Cole, M., \& Wertsch, J. V. (2007). Mediation: The Cambridge Companion to Vygotsky. Cambridge: Cambridge University Press.

Yoshikawa, H., Weiland, C., Brooks-Gunn, J., Burchinal, M., Espinosa, L., Gormley, W., \& Zaslow, M. J. (2013). Investing In Our Future: The Evidence Base For Preschool Education. Retrieved from the Foundation for Child Development website: fcd-us. org/sites/default/files/Evidence Base on Preschool Education Final.pdf.

Zins, J., Weissberg, R., Wang, M., \&Walberg, H. J. (Eds.). (2004). Building Academic Success on Social Emotional Learning: What Does the Research Say? New York: Teacher's College Press. 